\title{
Efficacy of Insecticides on Mites in Grape
}

\author{
D. Anitha Kumari*, G. Ram Reddy and D. Vijaya
}

SKLTSHU, Rajendranagar, Hyderabad, Telangana, India

*Corresponding author

\begin{tabular}{|l|}
\hline K e y w o r d s \\
Grape, Mites, \\
Insecticides, \\
Management \\
\hline Article Info \\
\hline $\begin{array}{l}\text { Accepted: } \\
\text { 20 December } 2018 \\
\text { Available Online: } \\
\text { 10 January } 2019\end{array}$ \\
\hline
\end{tabular}

\section{A B S T R A C T}

Mites pose an increasing threat to grape cultivation in grape growing areas in Telangana and Andhra Pradesh causing heavy loss in the field. Mites which are minor pests earlier in grapes have become serious, particularly before harvest of the crop in the recent years. Two species viz., Tetranychus urticae, and Eutetranychus orientalis are found causing damage to grapevine both in Telanagna and Andhra Pradesh. Among them, the two spotted red spider mite $T$. urticae causes severe loss. The present studies on population dynamics of mites in grape and their management were conducted at Grape research station, Rajendranagar, Hyderabad, during 2011-13. Studies on management of mites in grape were conducted in a completely randomized block design with seven treatments. The treatments include Abamectin@0.30 ml/l, Dicofol @ 2 ml/l, Sulphur @2 g/l, Fenpyroximate@1 ml/l, Spirotetramat @0.5 ml/l, Difenthurion50 SC @ 0.80 ml/l and Control. Among the tested treatments Abamectin@0.30 ml $/ 1$ was effective in the management of mites with 80.65 percent reduction of mites over control followed by Spirotetramat @ $0.5 \mathrm{ml} / 1$ with 78.5 percent reduction of mites over control. During 201213 Abamectin $0.5 \mathrm{ml} /$ lit was effective followed by Spirotetamat@0.5ml/lit with 81.53 and 74.31 percent reduction over control respectively after 10 days of second spray. High volume with high pressure water sprays help to reduce the dust and water stress. Increase the humidity in vineyard and also dislodge the mites from foliage thereby temporarily reducing the mite population.

\section{Introduction}

Grape (Vitis vinifera L.) is one of the most important fruit crops of temperate zone which has acclimatized to tropical and sub-tropical agro climatic conditions. Grape is fairly good source of minerals like calcium, phosphorous, iron and vitamins like $\mathrm{B}_{1}$ and $\mathrm{B}_{2}$. Fresh and dried fruits have various uses in Ayurvedic and Unani medicine. At present grape is cultivated in an area of 45,200 ha with an annual production of 10.57 lakh tones in India
(Mani, 2014). More than 85 species of insects have been reported in grapevine in India. Mites numbering 41 and nematodes numbering 113 were recorded as pest of grapes. More than 100 pests are known to attack the grapes in India (Butani, 1979).

Sunitha, 2017 reported that three species of mites viz., Tetranychus urticae, $T$. cinnabarinus, T. Euttetranychus orientalis are found causing damage to grapevine in India. Among them, the two spotted red spider mite 
T. urticae causes severe loss in Maharashtra, Karnataka and Andhra Pradesh.

Six species of mites viz., Tetrabychus urticae Koch, T. cinnabarinus Boisdual, $T$. neocoledonicus Andre, Oligonicus managiferus Rahmen and Sapra, O. punicae Baker and Eutetranuchus orientalis Klein are found causing damage to grapevine in India (Anonymous., 2008).

Out of these the infestation of Tetrabychus urticae is reported to be quite considerable in abundance and damage designating is as emerging sucking pests of grape these days (Chandra Sekhar et al.,2008). It has been confirmed recently (Veerendra et al., 2014) that Tetarnychus urticae relish the grapes in terms of their bionomics supporting continued pestiferousness.

Now it is known to cause severe yield loss both qualitatively and quantitatively through direct effects like loss of chlorophyll, stunting of growth, stippling, webbing, leaf yellowing, defoliation, leaf burning, reduction in size and quality of fruits and appearance of various types of plant deformities.

McDaniel spider mite (Tetranychus mcdaneli), Two-spotted spider mite (Tetranychus urticae), Willamette spider mite (Eotetranychus willametei), Yellow spider mite (Eotetranychus carpini borealis) are the different mites occurring in the grape gardens of pacific North West. Spider mites are not often a problem in low chemical input vineyards or with the use of "soft chemicals." Multiple applications of sulfur for disease management (more than five per season) tend to increase incidence and severity of spider mite problems by inhibiting the function of predators, particularly predatory mites (Phytoseiidae).

Grape rust mite (Calepitrimerus vitis Nalepa), an Eriophyid mite species, is known to be problematic in some grape-growing regions of the Pacific Northwest. Grape rust mites are obligate pests of Vitis vinifera grapes. Because of their economic damage potential, the mite now holds a permanent pest status in many grape-growing regions of the world including Germany, France, Spain, Switzerland, Italy, Brazil, Australia, and the Pacific Northwest of the USA (Bernard et al., 2005; Duso et al., 2010; Walton et al., 2007). Mites are most effectively moved by wind, followed by movement from vineyard laborers (Duso et al., 2010; Michalska et al., 2010).

Sanitation is to be maintained for eliminating the sources of the mite infestation. Spider mite outbreaks frequently occur where vines are dusty or stressed. Proper irrigation scheduling reduces the water stress and also increases the humidity thereby reducing the mite population. High volume with high pressure water sprays help to reduce the dust and water stress, increase the humidity in vineyard and also dislodge the mites from foliage thereby temporarily reducing the mite populations. The fungi Beauveria bassiana, Verticillium lecanii, Hirsutella thompsonii and Pacilomyces fumosoroseus are known to cause mortality in mites.(Kulkarni et al., 2008).

\section{Materials and Methods}

A field experiment was conducted on commercial thompson seedless variety from 2011-13 at Grape Research Station, Rajendranagar, Sri Konda Laxman Telangana State Horticultural University, Hyderabad to evaluate the efficacy of insecticides in the management of mites in grape. The experiment was conducted in a completely randomized block design with seven treatments. The treatment and three replications include Abamectin @ $0.50 \mathrm{ml} / \mathrm{l}$, Dicofol @ $2.5 \mathrm{ml} / \mathrm{l}$, Sulphur @ 2 g/l, Fenpyroximate@1 ml/1, Spirotetramat @ 0.5 ml/l, Difenthurion 50 SC @ $0.80 \mathrm{ml} / \mathrm{l}$ and Control. The first spray was given 
immediately after the incidence of mite infestation was observed and second spray was given one week after the first spray. Two application were targeted against mites (December to March) since the onset of their incidence. The observations were recorded on incidence of mites a day before and after one, five and ten days after each application. The mite population recorded was on per leaf basis and presented as mites /four leaves. The numbers of vines/treatment were five and cane /vine were three.

The total number of leaves considered for recoding mites was nine/cane which were selected randomly. The $7 \mathrm{x}$ magnifier hand lens was convenient to count the mites accurately. The berry yield was accounted $\mathrm{kg} / \mathrm{vine}$ and tons/ha. The data on mites was to $(x+0.5)$ before subjecting to analysis. The percent reduction over control was calculated for each insecticide and the data was subjected to statistical analysis.

\section{Results and Discussion}

Mites become more active in the month of February and the peak infestation is observed in March. Irrigation practices highly influence the development of mites. Drought stressed plants are most prone to mite outbreaks. Pest is highly active during summer months. There is outbreak of mites in hot dry conditions. High humidity and rainfall reduces mite numbers. Spider mite outbreaks frequently occur where vines are dusty or stressed. Proper irrigation scheduling reduces the water stress and also increases the humidity thereby reducing the mite population.

During 2011-12 and 2012-13 the percent reduction of mite population in various treatments was significant at each interval of observation (5, 10 days after first and second sprays).

\section{Percent population reduction after 5 days after the first spray}

During 2011-12 all the treatments were significantly superior over the control in reducing the mite population after 5 days of first spray. The treatment with Abamectin $0.5 \mathrm{ml} /$ lit was effective followed by Fenpyroximate@1.0ml/lit with 64.76 and 61.43 percent reduction over control respectively after 5 days of first spray.

During 2012-13 the treatment with Abamectin $0.5 \mathrm{ml} /$ lit was effective followed by Fenpyroximate@1.0ml/lit with 81.53 and 74.31 percent reduction over control respectively after 5 days of first spray.

\section{Percent population reduction after $\mathbf{1 0}$ days after the first spray}

Among all the treatments Abamectin 0.5ml/lit was effective followed by Fenpyroximate@1.0ml/lit with 63.20 and 58.32 percent reduction over control respectively after 10 days of second spray. During 2012-13 Abamectin 0.5ml/lit was effective followed by Fenpyroximate @ 1.0ml/lit with 80.92 and 74.54 percent reduction over control respectively after 10 days of second spray.

\section{Percent population reduction after 5 days after the second spray}

All the treatments were significantly superior over control after second spray. Among all the treatments Abamectin 0.5ml/lit was effective followed by Spirotetamat@0.5ml/lit, Difenthiuron, Fenpyroxymate, Sulphur and Dicofol after 5 days of second spray.

Among all the treatments Abamectin 0.5ml/lit was effective followed by Spirotetamat @ $0.5 \mathrm{ml} /$ lit with 80.65 and 79.97 percent reduction over control respectively 
after 10 days of second spray. During 201213 Abamectin $0.5 \mathrm{ml} /$ lit was effective followed by Spirotetamat $@ 0.5 \mathrm{ml} / \mathrm{lit}$ with 81.53 and 74.31 percent reduction over control respectively after 10 days of second spray.

Among the tested treatments Abamectin @ $0.30 \mathrm{ml} / \mathrm{l}$ was effective in the management of mites with 80.65 percent reduction of mites over control followed by Spirotetramat @ 0.5 $\mathrm{ml} / \mathrm{l}$ with 78.5 percent reduction of mites over control. During 2012-13 Abamectin 0.5ml/lit was effective followed by Spirotetamat@0.5ml/lit with 81.53 and 74.31 percent reduction over control respectively after 10 days of second spray (Table 1 and 2).

Table.1 Efficacy of different insecticides on mites in Grape (2011-13)

\begin{tabular}{|c|c|c|c|c|c|c|c|c|c|c|}
\hline \multirow[t]{3}{*}{ SI.No } & \multirow[t]{3}{*}{ Treatment } & \multicolumn{3}{|c|}{ Mites/leaf/Vine Precount } & \multicolumn{3}{|c|}{$\begin{array}{l}\text { Percent reduction over } \\
\text { control (after } 1^{\text {st }} \text { spray) }\end{array}$} & \multicolumn{3}{|c|}{$\begin{array}{l}\text { Percent reduction over } \\
\text { control (after } 1^{\text {st }} \text { spray) }\end{array}$} \\
\hline & & \multirow[b]{2}{*}{$\begin{array}{l}\text { (2011- } \\
\text { 12) }\end{array}$} & \multirow[b]{2}{*}{$\begin{array}{l}(2012- \\
13)\end{array}$} & \multirow{2}{*}{$\begin{array}{c}\text { Mean } \\
\text { (2011- } \\
\text { 13) }\end{array}$} & \multicolumn{2}{|c|}{5 DAS } & \multirow[t]{2}{*}{ Mean } & \multicolumn{2}{|c|}{10 DAS } & \multirow{2}{*}{$\begin{array}{c}\text { Mean } \\
\text { (2011- } \\
\text { 13) }\end{array}$} \\
\hline & & & & & $\begin{array}{l}(2011- \\
12)\end{array}$ & $\begin{array}{l}\text { (2012- } \\
\text { 13) }\end{array}$ & & $\begin{array}{l}(2011- \\
12)\end{array}$ & $\begin{array}{l}\text { (2012- } \\
\text { 13) }\end{array}$ & \\
\hline \multirow[t]{2}{*}{1} & \multirow{2}{*}{$\begin{array}{c}\text { Abamectin } \\
1.9 \% \mathrm{EC} \\
0.30 \mathrm{ml} / \mathrm{lit}\end{array}$} & 39.41 & 42.47 & 40.94 & $64.76^{\mathrm{a}}$ & $81.53^{\mathrm{a}}$ & 73.14 & $63.20^{\mathrm{a}}$ & $80.92^{\mathrm{a}}$ & $72.06^{\mathrm{a}}$ \\
\hline & & $(6.34)$ & $(6.59)$ & (6.46) & $(53.57)$ & $(64.57)$ & $(59.18)$ & $(52.65)$ & $(64.08)$ & $(58.36)$ \\
\hline \multirow[t]{2}{*}{2} & \multirow{2}{*}{$\begin{array}{c}\text { Dicofol } 18.5 \% \\
\text { EC } 2 \mathrm{ml} / \mathrm{lit}\end{array}$} & 42.85 & 42.20 & 42.52 & $49.90^{\mathrm{e}}$ & $65.79^{\mathrm{d}}$ & 35.34 & $49.31^{\mathrm{d}}$ & $67.26^{\mathrm{c}}$ & $58.28^{\mathrm{e}}$ \\
\hline & & $(6.62)$ & $(6.57)$ & (6.59) & $(44.92)$ & $(54.21)$ & $(49.56)$ & $(44.58)$ & $(55.14)$ & $(49.86)$ \\
\hline \multirow[t]{2}{*}{3} & \multirow{2}{*}{$\begin{array}{l}\text { Sulphur } 80 \% \\
\text { WP } 2 \text { g/lit }\end{array}$} & 39.05 & 40.87 & 39.96 & $52.73^{d}$ & $51.81^{\mathrm{e}}$ & 52.27 & $52.94^{c}$ & $54.47^{d}$ & $53.70^{d}$ \\
\hline & & $(6.32)$ & $(6.45)$ & (6.38) & $(46.55)$ & $(46.01)$ & $(46.28)$ & $(46.67)$ & $(47.55)$ & $(47.11)$ \\
\hline \multirow[t]{2}{*}{4} & \multirow{2}{*}{$\begin{array}{l}\text { Fenpyroximate } \\
5 \% \text { SC } 1 \mathrm{ml} / \mathrm{lit}\end{array}$} & 40.69 & 42.40 & 41.54 & $61.43^{b}$ & $74.31^{\mathrm{c}}$ & 67.87 & $58.32^{b}$ & $74.54^{b}$ & $66.43^{b}$ \\
\hline & & $(6.45)$ & $(6.58)$ & $(6.51)$ & $(51.60)$ & $(59.54)$ & $(55.57)$ & (49.77) & $(59.71)$ & $(54.74)$ \\
\hline \multirow[t]{2}{*}{5} & \multirow{2}{*}{$\begin{array}{c}\text { Spirotetramat } \\
120 \mathrm{OD} \\
0.50 \mathrm{ml} / \mathrm{lit}\end{array}$} & 38.81 & 42.07 & 40.44 & $58.43^{\mathrm{c}}$ & $68.45^{d}$ & 63.44 & $53.88^{c}$ & $69.74^{c}$ & $61.81^{c}$ \\
\hline & & $(6.30)$ & $(6.56)$ & (6.43) & $(49.84)$ & $(55.80)$ & $(52.82)$ & $(47.20)$ & $(56.61)$ & $(51.90)$ \\
\hline \multirow[t]{2}{*}{6} & \multirow{2}{*}{$\begin{array}{c}\text { Difenthiuron } \\
50 \% \mathrm{WP} \\
0.50 \mathrm{~g} / \mathrm{lit}\end{array}$} & 42.26 & 42.40 & 42.33 & $60.86^{\mathrm{b}}$ & $78.07^{b}$ & 69.46 & $53.56^{c}$ & $79.04^{\mathrm{a}}$ & $66.30^{b}$ \\
\hline & & $(6.57)$ & (6.58) & $(6.57)$ & $(51.26)$ & $(62.07)$ & $(56.66)$ & $(47.03)$ & $(62.74)$ & $(54.88)$ \\
\hline \multirow[t]{5}{*}{7} & \multirow{2}{*}{$\begin{array}{l}\text { Untreated } \\
\text { control }\end{array}$} & 40.43 & 39.70 & 40.06 & & & & & & \\
\hline & & (6.43) & $(6.37)$ & (6.40) & & & & & & \\
\hline & $\mathrm{CD}(5 \%)$ & N.S. & NS & NS & 2.21 & 3.81 & 3.01 & 1.79 & 3.91 & 2.85 \\
\hline & SEM & 0.15 & 0.19 & 0.17 & 0.74 & 1.69 & 1.22 & 0.60 & 1.73 & 1.16 \\
\hline & $\mathrm{CV}$ & 3.28 & 3.59 & 3.44 & 3.47 & 3.63 & 3.55 & 2.91 & 3.68 & 3.30 \\
\hline
\end{tabular}

*values in parenthesis are square root transformed 
Table.2 Efficacy of different insecticides on mites in Grape (2011-13)

\begin{tabular}{|c|c|c|c|c|c|c|c|c|c|c|}
\hline \multirow[t]{3}{*}{$\begin{array}{l}\text { Sl. } \\
\text { No }\end{array}$} & \multirow[t]{3}{*}{ Treatment } & \multicolumn{3}{|c|}{$\begin{array}{l}\text { Percent reduction over } \\
\text { control (after 2nd spray) }\end{array}$} & \multicolumn{3}{|c|}{$\begin{array}{l}\text { Percent reduction over } \\
\text { control (after } 2 \text { nd spray) }\end{array}$} & \multicolumn{3}{|c|}{ Yield(t/ha) } \\
\hline & & \multicolumn{2}{|c|}{5 DAS } & \multirow{2}{*}{$\begin{array}{c}\text { Mean } \\
\text { (2011- } \\
\text { 13) }\end{array}$} & \multicolumn{2}{|c|}{10 DAS } & \multirow{2}{*}{$\begin{array}{l}\text { Mean } \\
(2011- \\
13)\end{array}$} & \multirow[b]{2}{*}{$\begin{array}{l}(2011- \\
12)\end{array}$} & \multirow[b]{2}{*}{$\begin{array}{c}(2012- \\
13)\end{array}$} & \multirow{2}{*}{$\begin{array}{c}\text { Mean } \\
\text { (2011- } \\
\text { 13) }\end{array}$} \\
\hline & & $\begin{array}{l}(2011- \\
12)\end{array}$ & (2012- & & $\begin{array}{l}(2011- \\
12)\end{array}$ & $\begin{array}{l}\text { (2012- } \\
\text { 13) }\end{array}$ & & & & \\
\hline 1 & $\begin{array}{l}\text { Abamectin } \\
1.9 \% \mathrm{EC} \\
0.30 \mathrm{ml} / \mathrm{lit}\end{array}$ & $\begin{array}{c}78.53^{\mathrm{a}} \\
(62.42)\end{array}$ & $\begin{array}{c}80.92^{\mathrm{a}} \\
(64.08)\end{array}$ & $\begin{array}{c}79.72 \\
(63.25)\end{array}$ & $\begin{array}{l}80.65^{a} \\
(63.89)\end{array}$ & $\begin{array}{l}96.04^{\mathrm{a}} \\
(78.96)\end{array}$ & $\begin{array}{c}88.34 \\
(71.42)\end{array}$ & 24.77 & 26.54 & 25.65 \\
\hline 2 & $\begin{array}{l}\text { Dicofol } 18.5 \% \\
\text { EC } 2 \mathrm{ml} / \mathrm{lit}\end{array}$ & $\begin{array}{l}63.09^{d} \\
(52.58)\end{array}$ & $\begin{array}{r}67.26^{\mathrm{d}} \\
(55.14)\end{array}$ & $\begin{array}{c}65.17 \\
(53.86)\end{array}$ & $\begin{array}{l}70.20^{\mathrm{c}} \\
(56.9)\end{array}$ & $\begin{array}{l}72.92^{\mathrm{e}} \\
(58.97)\end{array}$ & $\begin{array}{c}71.56 \\
(57.93)\end{array}$ & 18.61 & 17.47 & 18.04 \\
\hline 3 & $\begin{array}{l}\text { Sulphur 80\% } \\
\text { WP } 2 \text { g/lit }\end{array}$ & $\begin{array}{l}65.66^{\mathrm{d}} \\
(54.18)\end{array}$ & $\begin{array}{r}54.47^{\mathrm{e}} \\
(47.55)\end{array}$ & $\begin{array}{c}60.06 \\
(50.56)\end{array}$ & $\begin{array}{r}68.83^{\mathrm{d}} \\
(56.04)\end{array}$ & $\begin{array}{r}71.87^{\mathrm{e}} \\
(57.99)\end{array}$ & $\begin{array}{c}70.35 \\
(57.01)\end{array}$ & 18.79 & 17.26 & 18.02 \\
\hline 4 & $\begin{array}{l}\text { Fenpyroximate } \\
5 \% \mathrm{SC} 1 \mathrm{ml} / \mathrm{lit}\end{array}$ & $\begin{array}{l}71.78^{\mathrm{c}} \\
(57.89)\end{array}$ & $\begin{array}{l}74.54^{\mathrm{c}} \\
(59.71)\end{array}$ & $\begin{array}{l}73.16 \\
(58.8)\end{array}$ & $\begin{array}{r}76.13^{b} \\
(60.74)\end{array}$ & $\begin{array}{r}77.96^{\mathrm{d}} \\
(62.09)\end{array}$ & $\begin{array}{c}77.04 \\
(61.41)\end{array}$ & 21.36 & 23.00 & 22.18 \\
\hline 5 & $\begin{array}{c}\text { Spirotetramat } \\
120 \mathrm{OD} \\
0.50 \mathrm{ml} / \mathrm{lit}\end{array}$ & $\begin{array}{c}73.34^{\mathrm{b}} \\
(58.89)\end{array}$ & $\begin{array}{c}69.74^{\mathrm{d}} \\
(56.61)\end{array}$ & $\begin{array}{c}71.54 \\
(57.75)\end{array}$ & $\begin{array}{c}79.97^{\mathrm{a}} \\
(63.40)\end{array}$ & $\begin{array}{l}89.22^{b} \\
(71.03)\end{array}$ & $\begin{array}{c}84.59 \\
(67.21)\end{array}$ & 24.20 & 16.78 & 20.49 \\
\hline 6 & $\begin{array}{l}\text { Difenthiuron } \\
50 \% \mathrm{SC} \\
0.8 \mathrm{ml} / \mathrm{lit}\end{array}$ & $\begin{array}{c}72.11^{b} \\
(58.11)\end{array}$ & $\begin{array}{c}79.04^{\mathrm{a}} \\
(62.74)\end{array}$ & $\begin{array}{c}75.57 \\
(60.42)\end{array}$ & $\begin{array}{c}75.55^{\mathrm{b}} \\
(60.36)\end{array}$ & $\begin{array}{c}81.29^{\mathrm{c}} \\
(64.38)\end{array}$ & $\begin{array}{c}78.42 \\
(62.37)\end{array}$ & 19.81 & 19.53 & 19.67 \\
\hline 7 & $\begin{array}{l}\text { Untreated } \\
\text { control }\end{array}$ & - & - & - & - & - & - & 14.16 & 13.86 & 14.01 \\
\hline & CD & 3.43 & 3.91 & 3.67 & 1.60 & 8.35 & 4.9 & 6.28 & 3.85 & 5.06 \\
\hline & SEM & 1.14 & 1.73 & 1.44 & 0.53 & 3.70 & 4.23 & 2.01 & 1.23 & 1.62 \\
\hline & $\mathrm{CV}$ & 4.66 & 3.68 & 4.17 & 2.07 & 6.92 & 4.49 & 17.25 & 11.15 & 14.2 \\
\hline
\end{tabular}

*values in parenthesis are square root transformed

Present studies indicate that the management of mites with acaricides is directly influencing the yield of grape and hence it is very much essential to manage the mites. During the recent years there is change in the emerging pest recent years there is change in the emerging pest scenario due to change in climate. Due to decreased rainfall and increased temperature in all the seasons mites are posing a serious threat to grapes and also other crops as well.

The superiority of abamectin in reducing the mite population was in conformity with the report of Karmate and Chandele (1997) in different crops Chandrashekar et al., (2008) also considered abamectin as the best insecticide for the management of mites in grapes followed by diferthuron, fenzaquin and spiromecifen.

The efficacy of abamectin and fenzaquin against different phytophagous mites is in conformity with Mani et al., (2003), Anand Kumar (2002), Singh et al., (2004) and Roopa (2005). Abamectin, spirotetramat, Difenthiuron were superior over the old conventional acaricide sulphur. It was reported that dicofol and sulphur were effective against $T$. urticae in grape by Kumar and Sharma (1991), Rao et al., (1995) Patel et al., (1993). In the present study in poor 
efficacy of Dicofol and Sulphur may be due to development of resistance.

Among the promising acaricides significantly, highest yield was obtained from Abamectin treatment (25-65 t/ha) followed by Spirotetramat (20.49 t/ha). However all the other acaricides yielded significantly high compared to untreated control in spite of their low activity. Thus the management of mites is very important in issues of economy point of view also.

In conclusion, the mite (Tetranychus urticae) is increasing in the recent years though it was a minor problem in the previous years. Among all the treatments for the management of mites in grape two sprays of Abamectin $0.5 \mathrm{ml} / \mathrm{lit}$ was effective followed by Spirotetamat @0.5ml/lit, Difenthiuron (0.5g/lit), Fenpyroxymate (1.0ml /lit). Further there is a scope for residue analysis as grape is a very important crop for export.

\section{References}

Anandkumar V, 2002. Survey and management of brinjal pests with special reference to biology of Leucinodes orbonalis Guen. M.Sc. (Agri.) Thesis, University of Agriculture Sciences, Dharwad (India).

Anonymous 2008. Management of mites of grapes Extension folder No.15, ICARNational Research Centre for Grapes, Pune (India).

Bernard M B P A, Horne A. A, Hoffmann. 2005. Eriophyoid mite damage in Vitis vinifera (grapevine) in Australia: Calepitrimerus vitis and Colomerus vitis (Acari: Eriophyidae) as the common cause of widespread 'Restricted Spring Growth' syndrome. Experimental and Applied Acarology 35: 83-109.
Butani D K, 1979. Insects and Fruits. Periodical Expert Book Agency, Delhi, India.

ChandraSekhar, D, Jagdishwar Reddy, D, Rahman, S.J, Ranga Reddy, A., Narendranath VV, 2008. Ecology and management of red spider mite Tertanychus urticae Koch on grape, In: Proceedings of International Symposium of Grape Production and Processing. Acta Horticulturae. 785, 335-347.

Duso C M, Castanoli S, Simoni G, Angeli, 2010. The impact of eriophyoids on crops: recent issues on Aculus schlechtendali, Calepitrimerus vitis and Aculops lycopersici. Experimental and Applied Acarology 51: 151-168.

Karmate B.K, Chandele A.G, 1997. Bioefficacy of new acaricides against two spotted spider mites, Tetranychus urticae Koch on roses in polyhouse. Pestology 21(7), 39-40.

Kulkarni N S, Mani M, and Banerjee K, 2008. National Research Centre for Grapes, Pune Management of Mites on Grapes. Extension Folder No. 15.

Mani C, Kumar S, Singh R N, 2003. Efficacy of acaricuides and botanicals against two spotted mite Tetranychus urticae Kho on okra. Annals of Plant Protection Sciences. 11(1),153-154.

Mani M, Shivaraju C S, Srinivasa Rao, 2014. Pest of grapevine: a world wide list. Pest Management in horticultural ecosystems. 20(2):170-216.

Michalska K A, Skoracka D, Navia, J W, Amrine, 2010. Behavioral studies on eriophyid mites: an overview. Experimental and Applied Acarology 51:31-59.

Roopa S. P, 2005. Investigations on mite pests of Solanaceous vegetables with special references to brinjal. Ph.D. Thesis, University of Agricultural Sciences, Dharwad, India. 
Singh D K, Sardana H R., Kadu, L N, 2004. Efficacy of certain pesticides against red spider mite, Tetranychus cinnabarinus Koch infesting Okra. Indian Journal Entomology 66(3),282284.

Sunitha N D, 2017. Population Dynamics of Grape Stem Borer Celosterna scabrator Fabr. (Cerambycidae: Coleoptera). Mysore Journal of Agricultural Sciences.51(2):276-280.

Veerendra A C, Udikeri S S, Karbhantanal S S, 2014. Comparative biology of two spotted spider mite, Tetranychus urticae Koch (Acariformes:

Tetrabychidae) on grape and mulberry. Karnataka Journal of Agricultural Sciences, 27(3), 351-352.

Walton V A J, Dreves D H, Gent R R, Martin U, Chambers P A, Skinkis, 2007. Relationship between rust mites, Calepitrimerus vitis (Acari: Eriophyidae), bud mites, Colomerus vitis (Acari: Eriophyidae) and Short Shoot Syndrome in Oregon Vineyards. International Journal of Acarology 33:1-12.

\section{How to cite this article:}

Anitha Kumari, D., G. Ram Reddy and Vijaya, D. 2019. Efficacy of Insecticides on Mites in Grape. Int.J.Curr.Microbiol.App.Sci. 8(01): 3000-3006.

doi: https://doi.org/10.20546/ijcmas.2019.801.319 